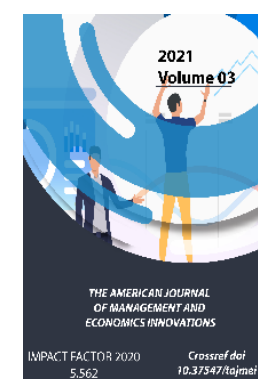

\title{
The Importance And Specific Features Of The Use Of Human Capital In The Development Of The Tourism Industry
}

\author{
Zilola Turobovna Jurayeva \\ Senior Teacher, Bukhara State University, Uzbekistan
}

Journal Website:

http://theamericanjour

nals.com/index.php/taj

mei

Copyright: Original

content from this work

may be used under the

terms of the creative

commons attributes

4.0 licence.

\section{ABSTRACT}

The article provides for the improvement of the tourism division at the current stage of economic improvement. Within the conditions of the digital economy, the importance and the need for the improvement and use of human capital is highlighted. The role of the use of human capital within the development of tourism, which is considered a vital branch of the economy, is also reflected in its characteristics. Also in the article, logical conclusions and proposals on the development of human capital are formed.

\section{KEYWORDS}

Tourism, digital economy, tourism services market, tourism products, human capital, science, innovation, modernization.

\section{INTRODUCTION}

In the conditions of transition to the "knowledge-based economy", tourism is considered one of the fastest growing sectors of the world economy. International tourism is among the three largest export sectors after oil production and automotive, according to other sources, tourism is the most profitable sector of the world economy.
Tourism is not only developed, but also developing, and even a relatively low level of development is a catalyst for the socioeconomic development of countries and territories. One new job created in the field of tourism is 20 times cheaper than in the industrial sector, while every 30 tourists visiting one country directly or indirectly 
create the opportunity to restore two new jobs.

\section{THE MAIN FINDINGS AND RESULTS}

The circle of tourism is a powerful "catalyst" of economic development of created and developing countries, provides the stream of foreign currency and investments, promotes the rapid growth of the circles that are close to it, helps in tackling the problems of work of the population and increments the country's reputation within the world community. It is possible to ensure that a huge sum of money will come up with a much lower cost when compared to other industries. Special consideration is paid to the errands for the advancement of tourism even within the socio-economic changes carried out in our country. In specific, within the procedure of action on five need ranges of advancement of the Republic of Uzbekistan in 2017-2021, assignments such as rapid development of the tourism industry, expanding its part and share within the economy, enhancement and quality enhancement of tourist services, expansion of tourism infrastructure are characterized [1].

In the structure of the national economy, the development of the tourism industry has its own characteristics, which is an expression of the following:

- The tourism industry is a complex system with a multifaceted functional structure aimed at meeting the needs of tourists, as well as covering specific forms and methods used in the provision of services;

- The tourism market offers a unique tourist product for tourists. The tourist product has a complex description and is presented in the form of a "package" of services necessary to meet the demand that arises during the trip;

- The main difference of the tourism sector from material production is that the achievement of the ultimate results in the provision of tourist services occurs directly with the participation of the consumer, as well as the implementation of the Consumer process directly in the place where there are tourist resources;

- Demand for tourist services has a high impact on changes in the socio-economic environment relative to market conditions. In this case, the security of tourism services will be of particular importance.

There are a number of positive effects of tourism on ecology, on the protection of the external environment. They consist of:

- To construct, reconstruction and protection of historical and cultural tourism objects;

- To limit the placement of industrial enterprises that harm the environment with the aim of developing nature conservation activities, keeping historical and cultural records;

- To support the development of production and transport infrastructure, service sectors based on new advanced innovative technologies;

- To create opportunities for the organization and development of natural zones, national parks, nature reserves, open nature museums in the arid.

As a result of the tourism potential of our 
country and the consistent reforms carried out in the field, tourism is developing. In particular, the number of organizations and enterprises providing tourist services, as well as the volume of services provided by them, is increasing (Figure 1).

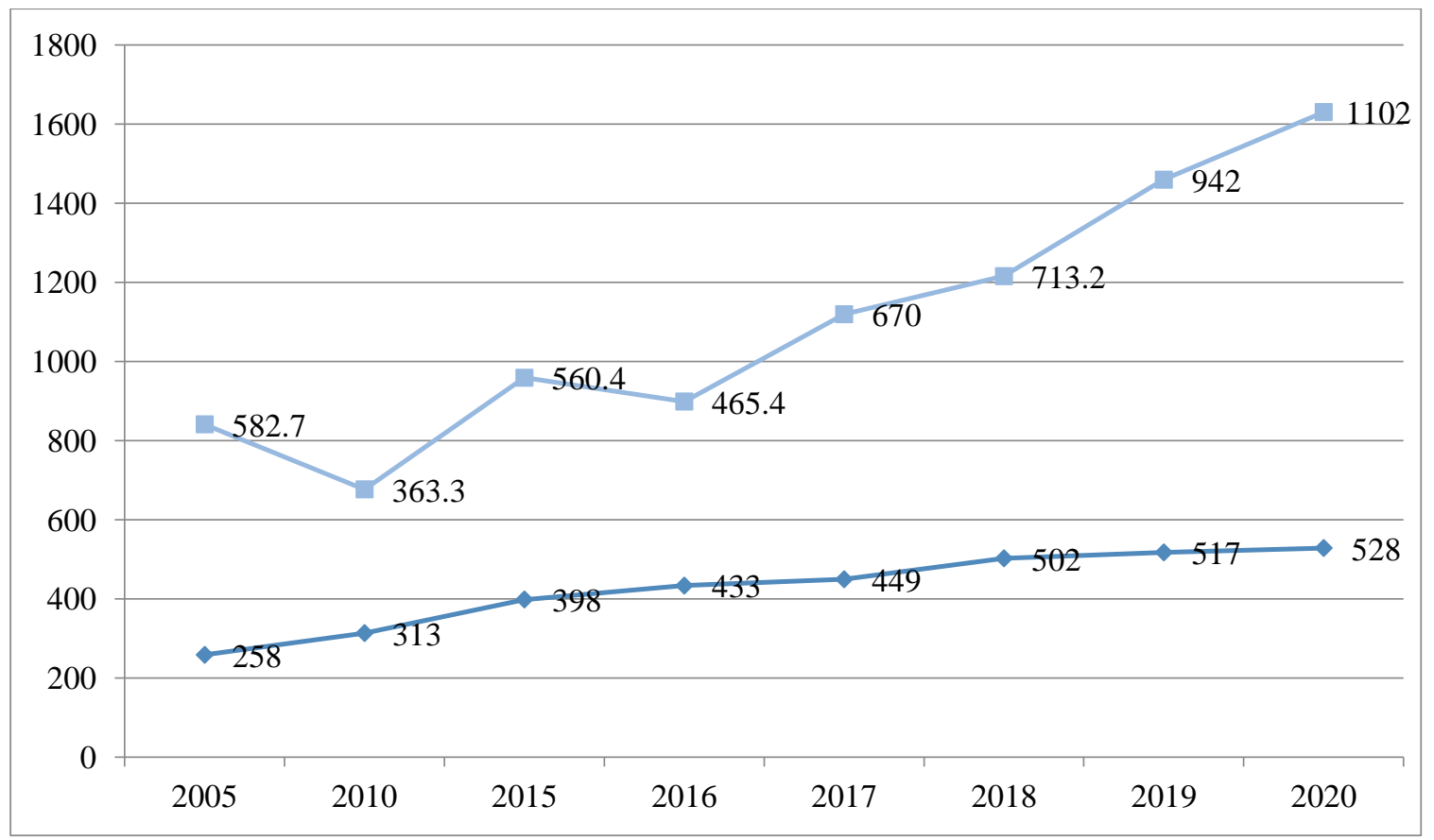

Figure 1. Dynamics of the number of tourist enterprises and their services in the Republic of Uzbekistan (Prepared by the author on the basis of www.stat.uz.)

As can be seen from the picture 1, the number of enterprises providing tourist services in 2005 amounted to 258 units, by 2020 the number of these enterprises increased by 2 times and amounted to 528 units. The number of visitors who are serviced by these enterprises is also increasing. In particular, in 2005, 582,7 thousand people were provided services by tourist enterprises, by 2020 the number of those served is almost 2 times, the number of 1102 thousand people.

As a result of the analysis, it is worthwhile to note that in recent years the following positive changes have been observed in the field of tourism in Uzbekistan:

- The constant holding of new international and local events aimed at the development of Tourism;

- The establishment of new educational institutions specializing in tourism;

- The consistent measures to increase the flow of tourists, modern and new tourist products, development of new directions of Tourism, Improvement of tourist infrastructure;

- To ensure the attractiveness of the tourist environment, as well as to attract foreign investors, etc.

At the present stage of transformation of the economy, the success of any state in innovation development largely depends on its effective conduct of public policy in the field of innovation and the qualitative formation of human capital. 
Therefore, it appears that human capital development must arise as a major factor of economic development. Today, the share of human capital in national wealth in developed countries is 80 percent. In this respect, special attention is paid to the development of human capital in the developed countries of the world.

Digitization combines technological, human, innovative resources of education, business and society spheres, creates and synthesizes integrations. As a result, innovative forms of educational services arise, which can be obtained throughout their entire working life by improving their human capital. Experts estimate that the digital part of the education market is characterized by steady growth and will reach about $\$ 240$ billion by 2023 , with an average annual growth of $17 \%$ [3].

The role of human capital in the socioeconomic development of society is one of the most important directions of scientific research in the world, which is based on the conditions created to ensure a decent life and sustainable development, economic growth, national originality, effective functioning of Man and fully realize his potential, while defining the country's position in the world community [2].

Human capital is a systematic expression of the essence of creating a useful product for society, the opportunities and abilities to engage in such activities, using the physical strength and health, knowledge, professional qualification skills, spiritual and moral printouts of a person in the present tense, as well as social relations formed in the process of education and upbringing in the family.

It is noted in the scientific literature that the human capital is this - the knowledge and skills of each person in reserve. Education, accumulation of professional experience, health protection, collection of information is an investment (source) of human capital. Such investments are of intangible importance and are the means by which human capital is formed. The tools that form the human capital are those that are presented in Figure 2 below.

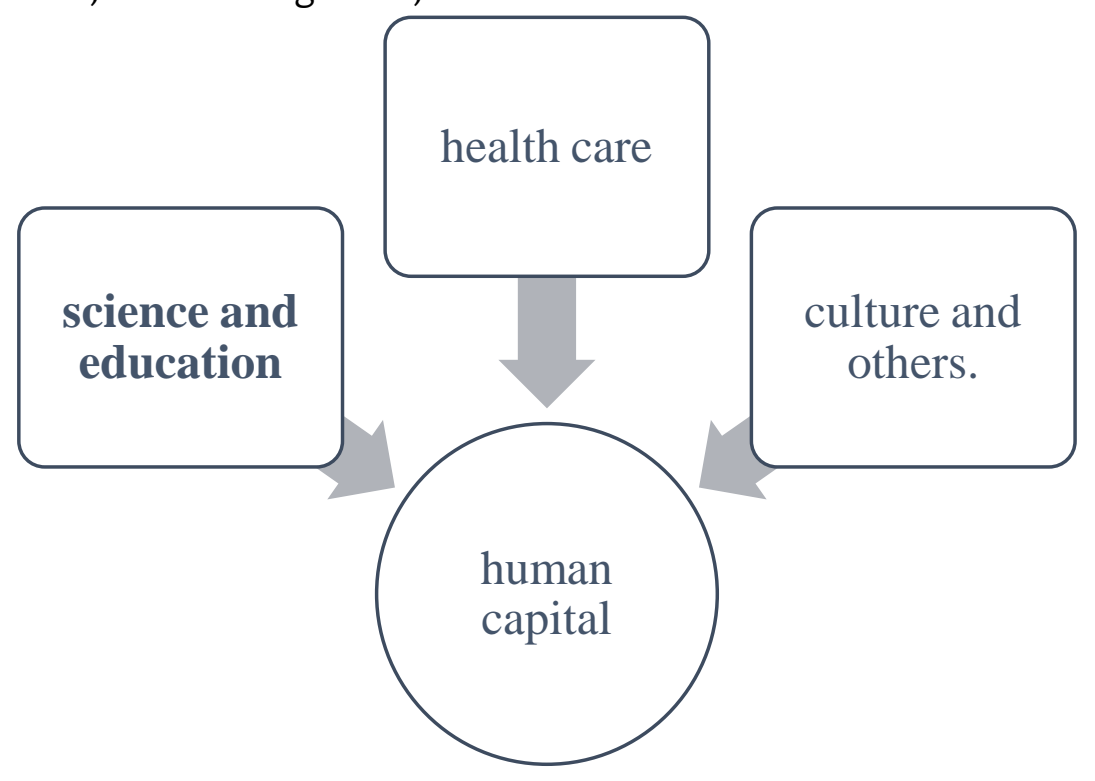




\section{Figure 2. Means that form human capital.}

Professor G.Abdurakhmanova noted that human capital in a narrow sense is a person's intellect, health, knowledge, quality and productive work, as well as his quality of life. In the broadest sense, human capital is an intensive productive factor of economic development, the development of society and the family, the educated part of the labor force, intellectual and managerial labor, the living and working environment. They must ensure that human capital development is effective and rational as a factor of production.

In our country, the importance of the index in 2006 year amounted to 0,63. However, in the following years there has been an increasing trend of the Human Potential Development Index, including in 2019 year it is 0,71 . This is evidenced by the increase in the quality of human capital in our country, the Republic of Uzbekistan ranks 105th in this regard and is among the countries with the highest level of human development.

Given the fact that human capital is the ability to generate income for a person, countries pay special attention to the development of human capital. Human capital is a factor that directly affects the pace of economic growth of the country. In addition, human capital also embodies the level of competitiveness of the country.

As a result of the research carried out within the framework of this topic, the following conclusions were formulated:
- With the rapid development of techniques and technologies, humanity is increasingly becoming the product of the fullness of society, which complicates the task of scientific research in terms of the formation and development of human capital, the structure of its sources and its impact on the environment;

- The change in production relations under the influence of digital technologies will undoubtedly lead to a change in the individual abilities and personal qualities of a person, which in the future will be reflected in the structure of professions and will affect the state of the labor market conjuncture;

- The scale of the change in human capital and the unification of professional requirements is explained by the development of a new type of institutional structure of public institutions as topical and effective means of transition of society to a more progressive state.

At the current stage of economic development, it is desirable to accelerate the processes of development of human capital, investment in human capital. Because the high scale and quality of expenditures on human capital will lead to the development of technical and technological industries with high scientific capacity; the level of innovative activity is also high, the level of technological armament in the production sector is high, and the level of professionalism of the employees is positive.

\section{CONCLUSION}

In conclusion, it is worthwhile to use human 
capital in the development of tourism, which is considered a strategic network of the economy. Because the use of science achievements in the development of the tourism services market helps to increase competitiveness and ensure a strong place in the market.

\section{REFERENCES}

1. Decree of the President of the Republic of Uzbekistan dated February 7, 2017 No PD-4947 "On the Action Strategy for further development of the Republic of Uzbekistan". https://lex.uz/docs/-3107036.

2. Magrupov A.Y. (2020) Socio-economic factors of human capital development in the digital economy. Author's abstract of the dissertation of the doctor of philosophy on economic sciences. Tashkent. - p. 63.

3. Dyatlov S.A., Khankhunova A.Yu. Features of the transformation of the human capital reproduction system in the digital economy // Izvestia SPbGEU. 2019. No. 2 (116).

4. Baranov, A.S. (2021) Information and excursion activities at tourism enterprises: textbook. A.S. Baranov, I.A. Bisko; ed. E.l. Bogdanov. - Moscow: INFRA-M. -p. 383.

5. Fedeneva, I.N. (2021) Organization of the tourism industry: a textbook for secondary vocational education. I. N. Fedeneva, V. P. Nekhoroshkov, L. K. Komarova; executive editor V.P. Nekhoroshkov. - 2nd ed., Rev. and add. Moscow: Yurayt Publishing House. - p. 205.

6. Safarova N.N. (2017) Scientific and theoretical bases of tourism development. Monograph. - Tashkent: - p. 220.

7. Golibjon, Y. (2016). Innovation and SME Development: Indonesian Experience in Uzbekistan Context. Journal of Entrepreneurship \& Organization Management, 5: 3. DOI: 10.4172/2169026X, 1000198.

8. www.stat.uz. 